\title{
Olfactory perceptual learning requires action of noradrenaline in the olfactory bulb: comparison with olfactory associative learning
}

\author{
Jennifer Vinera, ${ }^{1,2,3}$ Florence Kermen, ${ }^{1,2,3}$ Joëlle Sacquet, ${ }^{1,2,3}$ Anne Didier, ${ }^{1,2,3}$ \\ Nathalie Mandairon, ${ }^{1,2,3}$ and Marion Richard ${ }^{1,2,3}$ \\ ${ }^{1}$ INSERM, U1028; CNRS, UMR5292; Lyon Neuroscience Research Center, Neuroplasticity and Neuropathology of Olfactory \\ Perception Team, Lyon, F-69000, France; ${ }^{2}$ University of Lyon, F-69000, France; ${ }^{3}$ University Lyon 1, Villeurbanne, F-69000, France
}

\begin{abstract}
Noradrenaline contributes to olfactory-guided behaviors but its role in olfactory learning during adulthood is poorly documented. We investigated its implication in olfactory associative and perceptual learning using local infusion of mixed $\alpha 1-\beta$ adrenergic receptor antagonist (labetalol) in the adult mouse olfactory bulb. We reported that associative learning, as opposed to perceptual learning, was not affected by labetalol infusions in the olfactory bulb. Accordingly, this treatment during associative learning did not affect the survival of bulbar adult-born neurons. Altogether, our results suggest that the noradrenergic system plays different parts in specific olfactory learning tasks and their neurogenic correlates.
\end{abstract}

The mammalian main olfactory bulb (OB), which is the first cortical relay of olfactory information processing (Shepherd 1972), receives strong noradrenergic innervation from the Locus coeruleus (LC). Around $40 \%$ of LC neurons project to the OB, where the noradrenergic fibers innervate most OB layers, with a higher density of fibers in the internal plexiform and granule cell layers (Shipley et al. 1985; McLean et al. 1989). Noradrenaline modulates the activity of $\mathrm{OB}$ mitral cells, granular and periglomerular interneurons via interactions with both $\alpha$ and $\beta$ noradrenergic receptor subtypes (for review, see Linster et al. 2011). In addition to its impact on arousal and sensory processing in all modalities (for review, see Sara and Bouret 2012), noradrenaline plays a critical role in various olfactory-guided behaviors. For instance, in newborn rats, noradrenaline is involved in odor-based attachment to the mother (for review, see Landers and Sullivan 2012). In adult rodents, noradrenaline plays a role in pheromonal regulation of pregnancy and maternal behavior (Kaba et al. 1989; Brennan et al. 1990), in conspecific odor recognition (Shang and Dluzen 2001), and in behavioral habituation to odorants (Guérin et al. 2008). Within the bulbar network, noradrenaline actions are complex, dosedependent, and contribute to spontaneous and reward-motivated discrimination between perceptually similar odorants and recognition memory (Doucette et al. 2007; Mandairon et al. 2008; Escanilla et al. 2010, 2012; Manella et al. 2013). Although noradrenaline appears as a strong regulator of olfactory perception, its role in olfactory learning processes in adults remains poorly understood.

In this study, we aimed at investigating whether the noradrenergic system is involved in two main forms of olfactory learning in adult mice: olfactory perceptual learning and olfactory associative learning. Olfactory perceptual learning is an implicit, non-associative form of learning in which discrimination between perceptually similar odorants is improved following passive exposure to these odorants (Mandairon et al. 2006a,b). Olfactory associative learning is defined as the capacity to learn to associate an odorant with a reward (e.g., Sultan et al. 2010). To investigate the role of noradrenaline in these two forms of olfactory learning,

\section{Corresponding author: marion.richard@univ-lyon1.fr}

Article is online at http://www.learnmem.org/cgi/doi/10.1101/Im.036608.114. we infused in the mouse OB a mixed $\alpha_{1}-\beta$ noradrenergic receptor antagonist (labetalol) during learning and assessed the consequences of this local pharmacological manipulation on behavioral performances.

Male C57BL/6J mice (8 wk old, Charles Rivers, France) were housed under $12 \mathrm{~h}$ light/dark cycle with ad libitum access to water. Five days before and during the associative learning task, mice were food-restricted while keeping their body weight $\sim 85 \%$ of their initial weight. All behavioral testing was conducted in the afternoon (2-6 p.m.). Every effort was made to minimize the number of animals and their suffering during the experimental procedure (European directive 2010/63/UE, protocol no. DR2013-48).

We implanted stereotaxically (from bregma: AP: $+5 \mathrm{~mm}, \mathrm{ML}$ : $\pm 0.75 \mathrm{~mm}$, DV: $-1 \mathrm{~mm}$; Narishige Scientific Instruments, Japan) guide cannulae in the mice OBs after anesthesia $(100 \mathrm{mg} / \mathrm{kg}$ ketamine and $6 \mathrm{mg} / \mathrm{kg}$ xylazine, i.p.) and secured them with dental cement. Mice were equipped with dummy infusion cannulae to prevent blockage or infection and were allowed to recover from surgery before behavioral assessment. Labetalol $(13.7 \mathrm{mM}$ in $0.9 \%$ saline, Sigma-Aldrich; elimination half-life $=4-6 \mathrm{~h}$ Goodman Gilman et al. 1990) or saline solution was bilaterally infused into awake mice through the cannulae from 20 to $90 \mathrm{~min}$ before mice manipulation (see below for details) at a rate of $0.4 \mu \mathrm{L} / \mathrm{min}$ for $5 \mathrm{~min}$ (Harvard Pump). The infusion cannulae remained in place for an additional minute after the end of the infusion to minimize backflow. The dose of labetalol was in the same range as that of other noradrenergic antagonists used for intrabulbar infusions (Doucette et al. 2007, 2011; Mandairon et al. 2008; Escanilla et al. 2010, 2012).

We first verified that noradrenergic drug infusion had no effect on mice locomotion. Therefore, we assessed locomotor activity in an open field after labetalol $(n=9)$ or saline infusion $(n=7)$

\footnotetext{
(C) 2015 Vinera et al. This article is distributed exclusively by Cold Spring Harbor Laboratory Press for the first 12 months after the full-issue publication date (see http://learnmem.cshlp.org/site/misc/terms.xhtml). After 12 months, it is available under a Creative Commons License (AttributionNonCommercial 4.0 International), as described at http://creativecommons. org/licenses/by-nc/4.0/.
} 
( 2 min recording using a video camera and tracking software; Videotrack, Viewpoint). We observed no significant difference in mean locomotion speed between saline- and labetalol-infused mice (respectively $8.5 \pm 3.1 \mathrm{~cm} / \mathrm{sec}$ and $8.8 \pm 2.6 \mathrm{~cm} / \mathrm{sec}$ ) neither in total exploration time (respectively $92 \pm 18 \mathrm{sec}$ and $97 \pm$ $31 \mathrm{sec})(P>0.05$, bilateral unpaired $t$-test). These results showed that labetalol did not affect mice locomotion allowing further testing in two different olfactory learning tasks.

Perceptual learning was assessed as previously described (Mandairon et al. 2006a,b; Moreno et al. 2009, 2012). Briefly, the performances of discrimination between $(+)$ Limonene and ( -) Limonene were tested before and after an enrichment period with the same odorants, using a habituation/dishabituation task (Fig. 1A). The enrichment consisted in $1 \mathrm{~h}$ of exposure per day during $10 \mathrm{~d}$ to $100 \mu \mathrm{L}$ of pure (+) Limonene and (-) Limonene (purity $>97 \%$, Sigma-Aldrich). Labetalol or saline solution was bilaterally infused into awake mice $20 \mathrm{~min}$ before each enrichment period during $10 \mathrm{~d}$ (Fig. 1A). Mice were subsequently tested for discrimination in drug-free conditions (after at least a $24 \mathrm{~h}$ wash out). For the habituation/dishabituation task, (+) Limonene and (-) Limonene were presented in a tea ball $(60 \mu \mathrm{L}$ of odorant at $1 \mathrm{~Pa}$ ). A test session consisted in one $50 \mathrm{sec}$ presentation of mineral oil, then four $50 \mathrm{sec}$ presentations of the first odorant $(\mathrm{OHab})$ at 5 min intervals, followed by one 50 sec presentation of the second odorant of the pair (OTest). Investigation was defined as active sniffing within $1 \mathrm{~cm}$ of the tea ball. (+) Limonene and (-) Limonene were alternatively used as $\mathrm{OHab}$ or OTest. As expected, in preenrichment test session (Fig. 1B), both saline- and labetalol-infused mice habituated normally to the odor (OHab) (two-way ANOVA, repeated trial effect: $F_{(3,42)}=$ 28.65, $P<0.001$; treatment effect: $F_{(1,14)}=3.447, P=0.085$; trial/treatment interaction $\left.F_{(3,42)}=0.284, P=0.825\right)$ and did not discriminate $(+)$ Limonene from $(-)$ Limonene, as revealed by a similar investigation time of OHab4 and OTest (two-way ANOVA, trial effect $F_{(1,28)}=0.032, P=0.859$; treatment effect $F_{(1,28)}=2.137, P=0.155$; trial $/$ treatment interaction $F_{(1,28)}=$ $0.034, P=0.856)$. After a $10 \mathrm{~d}$ enrichment and infusion period, both saline- and labetalol-infused mice habituated normally (Fig. 1C) (two-way ANOVA, repeated trial effect: $F_{(3,42)}=24.418$, $P<0.001$; treatment effect: $F_{(1,14)}=0.232, P=0.637$; trial $/$ treatment interaction $\left.F_{(3,42)}=1.518, P=0.224\right)$. However, saline-infused mice discriminated $(+)$ Limonene from $(-)$ Limonene $(P<0.01)$ while labetalol-infused mice were not able to discriminate between the two enantiomers, indicating their inability to perform perceptual learning (Fig. 1C) (two-way ANOVA, trial effect $F_{(1,28)}=12.380, P=0.002$; treatment effect $F_{(1,28)}=5.814$, $P=0.023 ; \quad$ trial/treatment interaction $F_{(1,28)}=17.492, \quad P<$ $0.001)$. Thus, our results indicated that the local action of noradrenaline within the $\mathrm{OB}$ is required during enrichment for the acquisition of olfactory perceptual learning.

To pursue our evaluation of the role of noradrenaline in olfactory learning, we then tested whether its implication is taskdependent or generalized to other forms of learning. We thus investigated whether blocking bulbar noradrenaline also impairs olfactory associative learning. Olfactory associative learning was evaluated on a computer-assisted two-hole board apparatus as

A

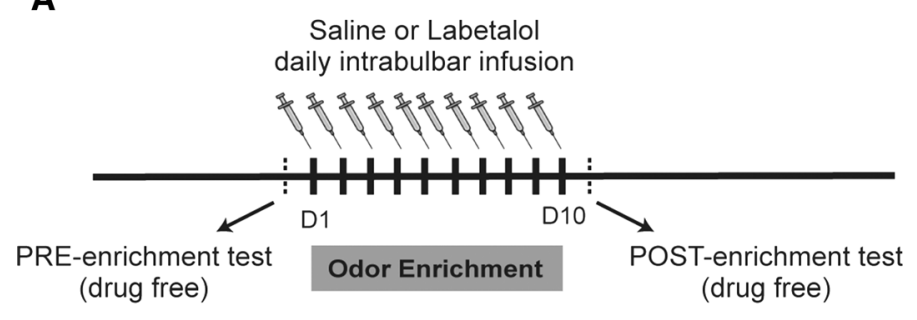

B

PRE-enrichment

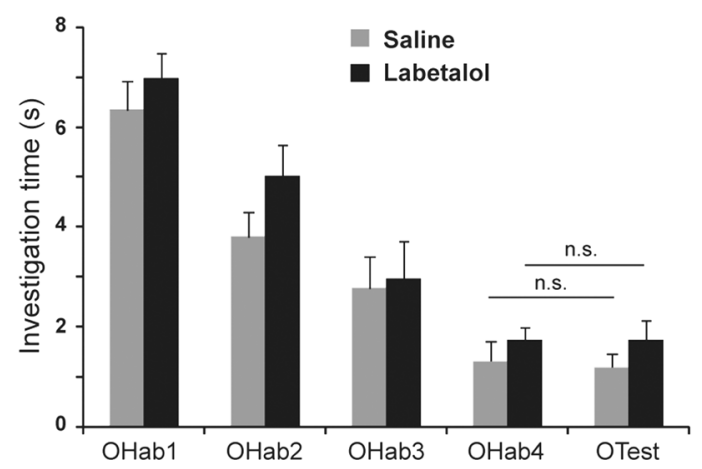

C

\section{POST-enrichment}

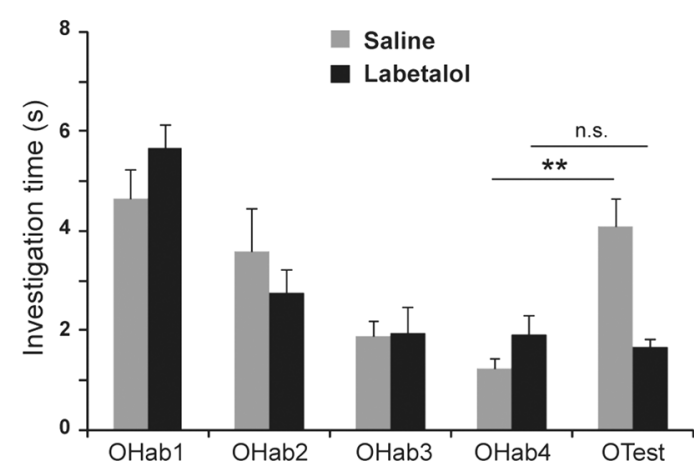

Figure 1. Labetalol-infused mice failed in the olfactory perceptual learning task. (A) Experimental design. Two groups of mice (saline $n=4$; labetalol $n=4$ ) underwent odor enrichment for $10 \mathrm{~d}$ and received intrabulbar infusion (labetalol or saline) 20 min before each odor enrichment session. (B) Habituation to OHab takes place and is similar in saline $(n=4)$ and labetalol-infused mice $(n=4)$ (OHab1 to OHab4) in drug-free preenrichment test. Discrimination is tested by comparing the investigation time between OHab4 and OTest. None of the mice discriminated $(+)$ and $(-)$ Limonene before enrichment (unilateral paired $t$-test, $P>0.05$ ). (C) After a 10-d odor enrichment and infusion period, both saline- and labetalol-infused mice $(n=4)$ habituated to OHab. However, saline-infused mice discriminated $(+)$ from $(-)$ Limonene (unilateral paired $t$-test, $P<0.01)$ whereas labetalol-infused mice did not $(P>0.05)$. All results are given as mean \pm SEM. $\left(^{* *}\right) P<0.01$, (n.s.) nonsignificant. 
A

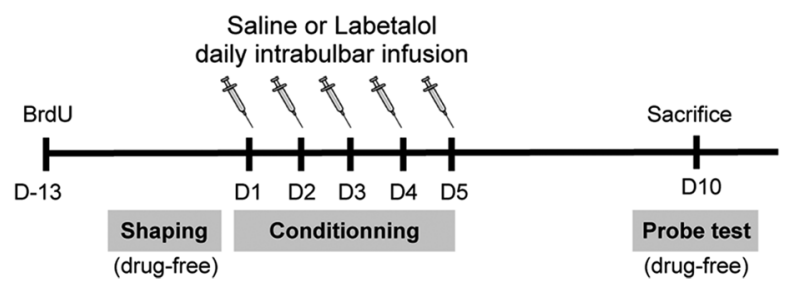

B
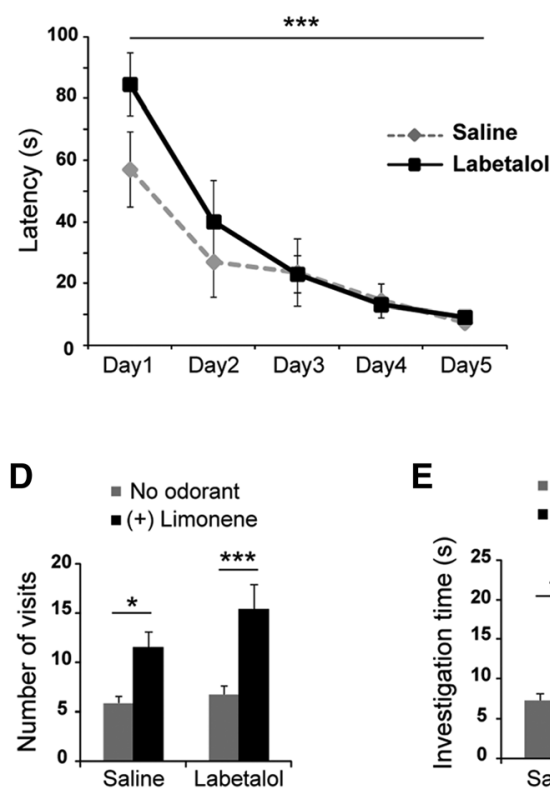

E

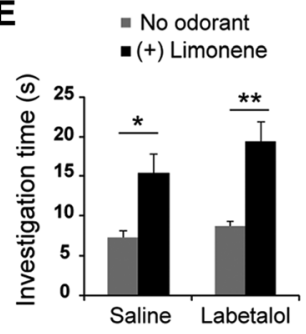

C

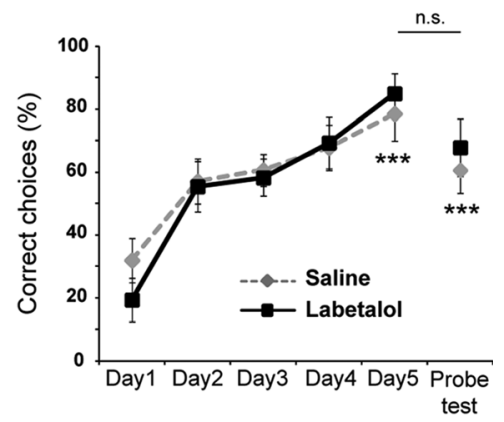

Figure 2. Labetalol-infused mice learned and remembered the olfactory associative task as well as the control mice. (A) Experimental design. Two groups of mice (saline $n=7$; labetalol $n=9$ ) underwent spaced olfactory associative learning for $5 \mathrm{~d}$ and received intrabulbar infusion (labetalol or saline) $20 \mathrm{~min}$ before each training session. BrdU was injected $13 \mathrm{~d}$ before training. Five days after the last session of conditioning (D10), mice underwent a probe test and were killed $1 \mathrm{~h}$ after the last trial. (B) Labetalol-infused mice learned the task like saline-infused ones as shown by the decrease in latency to find the reward associated with $(+)$ Limonene. $\left({ }^{* * *}\right) P<0.001$, Bonferroni post hoc test for comparison of Day 1 versus Day 5. (C) Both groups of mice showed an increase in the percentage of correct choices during the $5 \mathrm{~d}$ of conditioning. Five days after this training period (Probe test), labetalol- and saline-infused mice still displayed a high percentage of correct choices. $\left({ }^{* * *}\right) P<0.001$, Bonferroni post hoc tests for comparison of Day 1 versus Day 5 and Day 1 versus Probe test. (n.s.) nonsignificant $(P>0.05)$, Bonferroni post hoc test for comparison of Day 5 versus Probe test. Outlier trials that deviated from the mean by more than two SEM were excluded from analysis (one mouse out of 17). (D) Labetalol-infused mice, like control mice, visited the odorized hole $((+)$ Limonene) significantly more than the one without odorant. $(E)$ Labetalol- and saline-infused mice spent significantly more time investigating the odorized hole. $(*) P<0.05,(* *) P<0.01,\left({ }^{* * *}\right) P<0.001$, Bonferroni post hoc tests for comparison of $(+)$ Limonene versus nonodorized hole. $(F)$ Labetalol infusions did not affect newborn cell survival during olfactory associative learning, as assessed by the density of $\mathrm{BrdU}^{+}$cells in the granule cell layer of conditioned mice ( $23 \mathrm{~d}$ post-BrdU injection; $n=3$ mice for saline, $n=4$ mice for labetalol, $P>0.05$, bilateral unpaired $t$-test). All data are presented as mean $\pm \mathrm{SEM}$.

previously described (Mandairon et al. 2009; Sultan et al. 2010). Three weeks after cannula implantation (see above), mice were subjected to a shaping phase, during which they were trained along four-trial sessions (one session per day) to retrieve a reward (a small piece of cereal) by digging through the bedding without any odorant. Shaping was considered to be complete when a mouse could retrieve a buried reward in at least three out of four trials of one session. Once shaping criterion was reached, the animal started the conditioning phase during which it learned to associate an odorant $(20 \mu \mathrm{L}$ of pure $(+)$ Limonene impregnated onto a polypropylene swab) with a buried reward placed in one hole. The other hole contained neither odorant nor reward. Conditioning consisted of one session per day during $5 \mathrm{~d}$ (four trials per session; 2 min per trial, intertrial interval $=15 \mathrm{~min}$ ). To avoid spatial learning, the place of the odorized rewarded hole was randomized among the trials. Labetalol and saline intrabulbar infusions were performed $20 \mathrm{~min}$ before each training session (Fig. 2A). During each trial, the latency (time for the mouse to retrieve the reward) and the correct choice (the first nose poke is in the hole with odorant and reward) were recorded. Saline- and labetalolinfused mice learned the odor-reward association as shown by the overtime decrease in the latency to find the reward (Fig. 2B) and by the increase in the percentage of correct choices up to $80 \%$ (Fig. 2C) (for latency two-way ANOVA, treatment effect: $F_{(1,14)}=0.941 ; \quad P=$ 0.3484 ; day effect: $F_{(4,56)}=24.22 ; P<$ 0.0001 ; treatment/day interaction: $F_{(4,56)}=1.490, \quad P=0.2174$; for correct choices two-way ANOVA, treatment effect: $F_{(1,14)}=0.0212 ; P=0.8864 ;$ day effect: $F_{(5,70)}=12.92 ; P<0.0001$; treatment/day interaction: $F_{(5,70)}=0.5693$, $P=0.7232$ ). More precisely, post hoc tests revealed a significant difference between Day 1 versus Day 5 latency and percentage of correct choices for both groups (Fig. 2B,C; $P<0.001$ ). Hence, labetalol-infused animals learned the olfactory task as well as the control group. Altogether, these results demonstrate that labetalol infusion did not impact on the acquisition of the olfactory associative learning. We subsequently asked whether labetalol could impact on the memory retention of this task. Therefore, we performed a probe test $5 \mathrm{~d}$ after the last conditioning session, using the same conditions as during training except that the reward was not present. We previously reported that mice remembered this olfactory associative task $5 \mathrm{~d}$ after the conditioning (Sultan et al. 2010). In accordance with this result, saline-infused mice displayed a percentage of correct choices during the probe test that was not significantly different from the one at the end of the training session (Day 5) (Fig. 2C; $P>0.05$ ), demonstrating that saline-infused mice remembered the task. Interestingly, labetalol-infused mice displayed the same behavior (Fig. 2C; $P>0.05$ ). To precisely assess proper long-term memory of the task, we also defined two new criteria: the number of visits and the investigation time per hole. Both labetalol- and saline-infused mice visited the odorized hole significantly more often and longer than the nonodorized one (Fig. 2D,E) (number of visits two-way ANOVA, treatment effect: $F_{(1,14)}=0.5936 ; P=$ 0.4539; odor effect: $F_{(1,14)}=29.39 ; P<0.0001$; treatment/odor interaction: $F_{(1,14)}=0.6402, P=0.4370$; time investigating the odorized hole two-way ANOVA, treatment effect: $F_{(1,14)}=1.766$; 
$P=0.2051$; odor effect: $F_{(1,14)}=27.42 ; P<0.0001$; treatment $/$ odor interaction: $\left.F_{(1,14)}=0.4771, P=0.5010\right)$. Altogether, these results demonstrate that labetalol-infused mice still remembered the odor-reward association $5 \mathrm{~d}$ after conditioning. Thus, labetalol-infused mice were able to acquire and memorize the olfactory associative task, indicating that blocking noradrenergic signaling did not prevent the acquisition or the retention of the olfactory associative task.

In the $\mathrm{OB}$, new interneurons are continuously generated and integrated in the network during adulthood (Whitman and Greer 2009). Interestingly, we showed in a previous study that labetalol impairs both perceptual learning and learning-induced increase in neurogenesis (Moreno et al. 2012). Since neurogenesis is required for the long-term memory retention of the olfactory associative learning (Sultan et al. 2010), our current behavioral results showing that labetalol-infused mice are able to perform olfactory associative learning, suggest that the noradrenergic system is not involved in neurogenesis modulation in this type of learning. To test this hypothesis, we assessed the survival of adult-born neurons in the $\mathrm{OB}$ of labetalol-infused mice submitted to olfactory associative learning and compared it with saline-infused mice which were similarly conditioned. In order to measure adult-born cell survival, the DNA synthesis marker BrdU (5-bromo-2'-deoxyuridine) was administered $13 \mathrm{~d}$ before the beginning of the conditioning session (Fig. 2A), with three i.p. injections $(50 \mathrm{mg} / \mathrm{kg}$ in $0.9 \%$ saline) at $2 \mathrm{~h}$ intervals. This protocol allowed to label a cohort of adult-born neurons integrating the $\mathrm{OB}$ at the beginning of training and thus within the critical period of their learningdependent survival (Mouret et al. 2008). One hour after the probe test ( $23 \mathrm{~d}$ post-BrdU injection), four mice were randomly taken from each group, deeply anesthetized (pentobarbital $0.2 \mathrm{~mL} /$ $25 \mathrm{~g}$ ) and killed by intracardiac perfusion of $4 \%$ paraformaldehyde (in PBS, $\mathrm{pH}=7.4$ ). $\mathrm{BrdU}^{+}$cells were revealed on frozen $\mathrm{OB}$ sections by immunohistochemistry (anti-BrdU antibody, 1:100, Millipore, USA) as previously described in detail (Mandairon et al. 2006c). BrdU ${ }^{+}$cell density within the granule cell layer was similar in labetalol-infused OBs compared with saline-infused ones ( $P=0.34$; Fig. 2F) (Mercator software, Explora Nova, France). This result indicated that the survival of adult-born granule cells during associative learning is not affected by labetalol in our experimental conditions, in accordance with the behavioral results showing that labetalol infusion did not impair associative learning and its retention (Fig. 2).

In this study, we investigated the role of local noradrenaline within the $\mathrm{OB}$ on olfactory perceptual and associative learning, by locally infusing labetalol, a mixed $\alpha_{1}-\beta$ adrenergic receptor antagonist. Our group previously showed that perceptual learning is dependent on noradrenaline by labetalol i.p. injection (Moreno et al. 2012). The results presented here go further and demonstrate that this noradrenergic requirement for perceptual learning is locally circumscribed to the OB. In addition, we reported that labetalol-infused mice could not perform olfactory perceptual learning but perfectly learned and memorized the olfactory associative task. At the same concentration, labetalol thus differentially affect perceptual and associative learning, indicating that these two forms of olfactory learning, respectively an unrewarded and a rewarded task, have differential requirement toward noradrenaline action within the OB. Instead of acting as a global bulbar modulator, noradrenaline might have a finely tuned action on the $\mathrm{OB}$ depending on the type of olfactory behavior at stake. Alteration of the noradrenergic system might thus lead to some of the reported age-associated olfactory learning deficits (Rey et al. 2012; Moreno et al. 2014). Our results do not deny the possibility that noradrenergic transmission might be required for olfactory associative learning in other brain areas, such as in the hippocampus, amygdala, piriform cortex, and basolateral amygdala (Miranda et al. 2007; Debiec et al. 2011; Linster et al. 2011).

Noradrenaline could act, at least partly, through the regulation of adult neurogenesis in the OB. Indeed, olfactory perceptual and associative learning differently depend on adult neurogenesis. Contrary to olfactory perceptual learning which requires adult neurogenesis for acquisition of the task (Moreno et al. 2009), olfactory associative learning requires neurogenesis for the longterm memory retention but not for the acquisition of the task (Sultan et al. 2010). The noradrenergic signaling pathway might be one of the mechanisms underlying the different implication of neurogenesis depending on the behavioral task, by providing a modulated top-down control during these learning processes. Previous works in our laboratory showed that noradrenaline may act as a key mechanism controlling both learning-dependent neurogenesis during perceptual learning (Moreno et al. 2012) and the contribution of novelty to the beneficial effects of olfactory enrichment on memory and neurogenesis (Veyrac et al. 2009). In the current study, labetalol did not affect cell survival in conditioned mice, in accordance with the lack of behavioral effect. This result suggests that adult-born cell survival in the context of associative learning is regulated by mechanisms distinct from those at play in perceptual learning or global enrichment. One can hypothesize that other neuromodulatory systems could contribute to adult-born cell survival and thereby ensure olfactory associative learning. Serotoninergic activation is likely to play an important role in olfactory associative conditioning and short-term memory (Moriizumi et al. 1994; Fletcher and Chen 2010). Acetylcholine is also involved in associative olfactory learning, notably odorshock associations (Kroon and Carobrez 2009; Pavesi et al. 2013). Hence, more studies are needed to determine the specific contribution of these neuromodulatory systems in olfactory associative learning and in the regulation of adult $\mathrm{OB}$ neurogenesis.

In conclusion, this study shed new light on the role of the noradrenergic system during olfactory learning. Depending on the behavioral task, different mechanisms seem to be involved. The noradrenergic signaling pathway is likely to differentially take part in the modulation of the $\mathrm{OB}$ circuitry, including the promotion of adult neurogenesis in response to specific cognitive demands.

\section{Acknowledgments}

This work was supported by the University Claude Bernard Lyon 1 (BQR 2013), CNRS, and INSERM.

\section{References}

Brennan P, Kaba H, Keverne EB. 1990. Olfactory recognition: a simple memory system. Science 250: $1223-1226$

Debiec J, Bush DE, LeDoux JE. 2011. Noradrenergic enhancement of reconsolidation in the amygdala impairs extinction of conditioned fear in rats-a possible mechanism for the persistence of traumatic memories in PTSD. Depress Anxiety 28: 186-193.

Doucette W, Milder J, Restrepo D. 2007. Adrenergic modulation of olfactory bulb circuitry affects odor discrimination. Learn Mem 14: $539-547$.

Doucette W, Gire DH, Whitesell J, Carmean V, Lucero MT, Restrepo D. 2011. Associative cortex features in the first olfactory brain relay station. Neuron 69: 1176-1187.

Escanilla O, Arrellanos A, Karnow A, Ennis M, Linster C. 2010. Noradrenergic modulation of behavioral odor detection and discrimination thresholds in the olfactory bulb. Eur J Neurosci 32: $458-468$.

Escanilla O, Alperin S, Youssef M, Ennis M, Linster C. 2012. Noradrenergic but not cholinergic modulation of olfactory bulb during processing of near threshold concentration stimuli. Behav Neurosci 126: 720-728.

Fletcher ML, Chen WR. 2010. Neural correlates of olfactory learning: critical role of centrifugal neuromodulation. Learn Mem 17: 561-570. 
Goodman Gilman A, Rall TW, Nies AS, Taylor P. 1990. Goodman and Gilman's the pharmacological basis of therapeutics. Pergamon Press, New York.

Guérin D, Peace ST, Didier A, Linster C, Cleland TA. 2008. Noradrenergic neuromodulation in the olfactory bulb modulates odor habituation and spontaneous discrimination. Behav Neurosci 122: 816-826.

Kaba H, Rosser A, Keverne B. 1989. Neural basis of olfactory memory in the context of pregnancy block. Neuroscience 32: 657-662.

Kroon JA, Carobrez AP. 2009. Olfactory fear conditioning paradigm in rats: effects of midazolam, propranolol or scopolamine. Neurobiol Learn Mem 91: $32-40$.

Landers MS, Sullivan RM. 2012. The development and neurobiology of infant attachment and fear. Dev Neurosci 34: 101-114.

Linster C, Nai Q, Ennis M. 2011. Nonlinear effects of noradrenergic modulation of olfactory bulb function in adult rodents. J Neurophysiol 105: $1432-1443$.

Mandairon N, Stack C, Kiselycznyk C, Linster C. 2006a. Enrichment to odors improves olfactory discrimination in adult rats. Behav Neurosci 120: $173-179$

Mandairon N, Stack C, Kiselycznyk C, Linster C. 2006b. Broad activation of the olfactory bulb produces long-lasting changes in odor perception. Proc Natl Acad Sci 103: 13543-13548.

Mandairon N, Sacquet J, Jourdan F, Didier A. 2006c. Long-term fate and distribution of newborn cells in the adult mouse olfactory bulb: influences of olfactory deprivation. Neuroscience 141: 443-451.

Mandairon N, Peace S, Karnow A, Kim J, Ennis M, Linster C. 2008. Noradrenergic modulation in the olfactory bulb influences spontaneous and reward-motivated discrimination, but not the formation of habituation memory. Eur I Neurosci 27: 1210-1219.

Mandairon N, Sultan S, Rey N, Kermen F, Moreno M, Busto G, Farget V, Messaoudi B, Thevenet M, Didier A. 2009. A computer-assisted odorized hole-board for testing olfactory perception in mice. J Neurosci Methods 180: 296-303.

Manella LC, Alperin S, Linster C. 2013. Stressors impair odor recognition memory via an olfactory bulb-dependent noradrenergic mechanism. Front Integr Neurosci 7: 97.

McLean JH, Shipley MT, Nickell WT, Aston-Jones G, Reyher CK. 1989. Chemoanatomical organization of the noradrenergic input from Locus coeruleus to the olfactory bulb of the adult rat. J Comp Neurol 285: 339-349.

Miranda MA, Ferry B, Ferreira G. 2007. Basolateral amygdala noradrenergic activity is involved in the acquisition of conditioned odor aversion in the rat. Neurobiol Learn Mem 88: 260-263.
Moreno MM, Linster C, Escanilla O, Sacquet J, Didier A, Mandairon N. 2009. Olfactory perceptual learning requires adult neurogenesis. Proc Natl Acad Sci 106: 17980-17985.

Moreno MM, Bath K, Kuczewski N, Sacquet J, Didier A, Mandairon N. 2012. Action of the noradrenergic system on adult-born cells is required for olfactory learning in mice. J Neurosci 32: 3748-3758.

Moreno MM, Richard M, Landrein B, Sacquet J, Didier A, Mandairon N. 2014. Alteration of olfactory perceptual learning and its cellular basis in aged mice. Neurobiol Aging 35: 680-691.

Moriizumi T, Tsukatani T, Sakashita H, Miwa T. 1994. Olfactory disturbance induced by deafferentation of serotonergic fibers in the olfactory bulb. Neuroscience 61: 733-738.

Mouret A, Gheusi G, Gabellec MM, de Chaumont F, Olivo-Marin JC, Lledo PM. 2008. Learning and survival of newly generated neurons: when time matters. J Neurosci 28: 11511-11516.

Pavesi E, Gooch A, Lee E, Fletcher ML. 2013. Cholinergic modulation during acquisition of olfactory fear conditioning alters learning and stimulus generalization in mice. Learn Mem 20: 6-10.

Rey NL, Sacquet J, Veyrac A, Jourdan F, Didier A. 2012. Behavioral and cellular markers of olfactory aging and their response to enrichment. Neurobiol Aging 33: 626.e9-626.e23.

Sara SJ, Bouret S. 2012. Orienting and reorienting: the Locus coeruleus mediates cognition through arousal. Neuron 76: 130-141.

Shang Y, Dluzen DE. 2001. Nisoxetine infusion into the olfactory bulb enhances the capacity for male rats to identify conspecifics. Neuroscience 104: 957-964.

Shepherd GM. 1972. Synaptic organization of the mammalian olfactory bulb. Physiol Rev 52: 864-917.

Shipley MT, Halloran FJ, de la Torre J. 1985. Surprisingly rich projection from Locus coeruleus to the olfactory bulb in the rat. Brain Res 329: 294-299.

Sultan S, Mandairon N, Kermen F, Garcia S, Sacquet J, Didier A. 2010. Learning-dependent neurogenesis in the olfactory bulb determines long-term olfactory memory. FASEB J 24: 2355-2363.

Veyrac A, Sacquet J, Nguyen V, Marien M, Jourdan F, Didier A. 2009. Novelty determines the effects of olfactory enrichment on memory and neurogenesis through noradrenergic mechanisms. Neuropsychopharmacology 34: 786-795.

Whitman MC, Greer CA. 2009. Adult neurogenesis and the olfactory system. Prog Neurobiol 89: 162-175.

Received July 31, 2014; accepted in revised form January 7, 2015. 


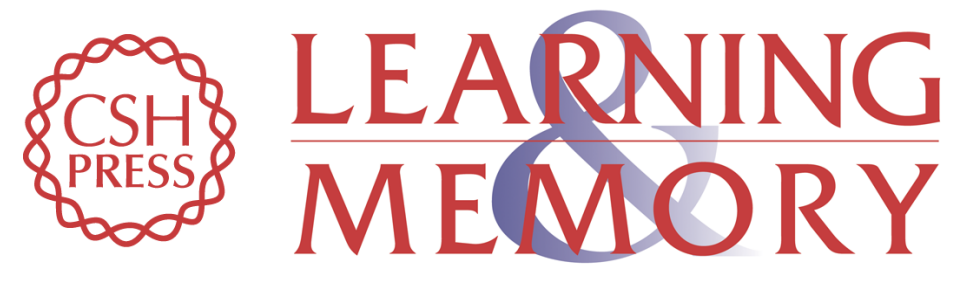

\section{Olfactory perceptual learning requires action of noradrenaline in the olfactory bulb: comparison with olfactory associative learning}

Jennifer Vinera, Florence Kermen, Joëlle Sacquet, et al.

Learn. Mem. 2015, 22:

Access the most recent version at doi:10.1101/lm.036608.114

References This article cites 34 articles, 7 of which can be accessed free at:

http://learnmem.cshlp.org/content/22/3/192.full.html\#ref-list-1

Creative This article is distributed exclusively by Cold Spring Harbor Laboratory Press for the

Commons first 12 months after the full-issue publication date (see

License

http://learnmem.cshlp.org/site/misc/terms.xhtml). After 12 months, it is available under a Creative Commons License (Attribution-NonCommercial 4.0 International), as described at http://creativecommons.org/licenses/by-nc/4.0/.

Email Alerting Receive free email alerts when new articles cite this article - sign up in the box at the Service top right corner of the article or click here. 